DOI: $10.17516 / 1997-1370-0566$

УДК 81 '25

\title{
Cognitive Political Discourse Analysis: Creative Translation Teaching Case
}

\section{Irina V. Ubozhenko}

National Research University Higher School of Economics

Moscow, Russian Federation

Received 02.10.2019, received in revised form 14.02.2020, accepted 10.03.2020

\begin{abstract}
The paper elaborates on teaching creative translation and analyses the case of cognitive political discourse and its translation decision-making process. The research is based on the example of modern political terminology and non-equivalent political context vocabulary. Unlike traditional approaches that mostly relate creativity to literary texts interpretation, the study deals with the didactic methodology of comprehending and translating foreign academic and popular science sources. The cognitive comparative analysis of political concepts in their context use - both in English and Russian discourse is aimed at professional explanation of motivation in selecting and choosing translation equivalents. The algorithm of designing an associative thesaurus referred to cognitive signs of lexical marking has been a major investigation tool of political discourse analysis represented in the paper as well as the foundation for the original creative model of translation performance and didactics.
\end{abstract}

Keywords: political discourse, teaching translation creativity, intuition in translation, translation cognitive modeling.

Research area: linguistics and translation studies.

Citation: Ubozhenko, I.V. (2020). Cognitive political discourse analysis: creative translation teaching case. J. Sib. Fed. Univ. Humanit. Soc. Sci., 13(3), 363-374. DOI: 10.17516/1997-1370-0566.

(C) Siberian Federal University. All rights reserved

* Corresponding author E-mail address: iubojenko@hse.ru ORCID: 0000-0003-0093-4690 


\section{The Research Relevance and Novelty}

The research of creative approaches to translation of informative texts suggests a novel view compared to the current studies of literary language and literary translation. The issue of the fundamentals of linguistic creativity, interdisciplinary by nature and highly debatable, presents a gamut of topical research challenges, and investigating didactic principles of creative translation process has been one of the most empirically resourceful and valuable.

The paper illustrates the first interdisciplinary research attempt made to combine the methods of translation didactics and political science through using cognitive paradigm fundamentals with the aim to explore highly urgent issues of both political cognition and translation studies linked to the cross-cultural conceptual analysis of basic political notions, their adequate interpreting, and consequently, operationalizing through translation.

In the paper the development of professional skills to make successful linguistic decisions while teaching translation of foreign (in our case English) academic texts (into Russian) is based on detailed cognitive analysis of parallel political discourses that finally results in mastering the academic faculties of choosing the correct translation equivalent involving all modern political background knowledge. Another research objective has been to create an integrated parallel bilingual thesaurus (glossary) comprising some definite representative cases of the examined subject fields of linguistic (political) realities units usage (such conceptual notions in the world politics as "governance", "accountability", "state", etc.).

Thus the creative model of teaching translation offers an original associative mind-mapping scheme method of cognitive analysis and a novel didactic metalinguistic tool kit of making appropriate professional translation decisions in dealing with political discourse. Besides, the author's term "translation creative occasionalism" is introduced and illustrated in the paper.

\section{Research Background and Methodological Framework}

Translation studies today have taken a new turn in different research directions: in theory, teaching didactics, such applied fields as IT-translation, as well as various machine translation platforms development. This primarily is related to the launch to the translation industry market of a number of special computer programs and, what is more, neuro nets. In this regard, the interest of scholars to studying the anthropocentric translation phenomena has been increasingly growing, based on such linguistic paradigms and frameworks as language and cognition, language and mind, and taking into account the research concepts of natural vs. artificial intelligence and its actual representation in language and speech. All mentioned above justifies fairly to the fact that linguistic translatology introduced in the past century has vividly become a renewed field of science that now relies on cognitive, interpretive, and creative approaches. This novelty makes us shed a new light on the issues of the translation process and its reflexive interpreting, intuition in translation, translation creativity. The study is aimed at the raised question of the translator's intuition and his/her cognitive and mental/intellectual ability to create new versions and variants of translation.

The research is an attempt to suggest a theory of possible universal logical modeling of the translation process. It must be underlined here that our objective is to model the analytical operations with no concrete regard to traditional translation types (translating and interpreting) and their distinguished features: it is the fundamentals of cognitive theory that make the starting research push for our investigation. Moreover, the variants of interpreting the message of the original and the appropriate translation versions are being studied with the emphasis on inherent intuitive and creative skills of a translator, which are seen as possible to be further developed, initiated and activated in professional translation activity.

We start with claiming that the core role in the translation process is played by the one, who interprets the original (consciously or unconsciously): the translator with their all personal life and language experience. The studied literature on the research theme gives us a reasonable ground to formulate major theoretic axioms, which we see as basic fundamentals 
for our creative model of the translation process.

1. In translation studies a huge number of research questions have been referred to the sphere of intuitive, subjective and individual aspects.

2. The translation process is of heuristic nature and involves a sequence of certain stages, when an adequate version is being chosen of all possible alternatives. These stages are actually mental states/mind operations of creative origin often performed by the translator intuitively using his/her knowledge, communicative competence and the intellectual ability to evaluate cognitive and culture specific distinguishing features of the translation recipient.

3. In order to reveal and describe the mental acts leading to the choice and interpretation of language units, it is necessary to make an attempt to describe the process, when the translator is shaping in their mind the mental representations of alternative translation options, and then makes a resulting final decision.

4. The analysis of reasons, ways, steps and varieties of choice in mental operations of a translator is of significant theoretic and applied research value, as it offers a chance to open "the black box" of a translator striving to observe the processes in his/her brain working.

The idea of the research initially derived from the author's previous investigations of the translator's intuition and creativity and her experimental attempts of thesaurus modeling of human thinking that finally resulted in the original methodical algorithm of teaching ingenuity in the field of practical translation.

As it is known, terminology and the socalled non-equivalent lexical units have been one of the most challenging, while making translation. In the given study of all nowadays heatedly debated in the world political science issues - such as government and governance, state, power, etc. - accountability has been chosen as a major research question due to its being truly polysemantic, context dependent, multifaceted, and abounding in shadows of probable meaning explanations. Judging by the political research experience accumulated by now the number of accountability types has been really impressive: general and specific ac- countability (Goodin, 2004), external, internal, and transnational (Keohane, 2006), democratic (Behn, 2001; Sharpf, 2003; Goodin, 2004), legal and political (Ku, Jacobson, 2003), horizontal and vertical accountability (Morlino, 2009), accountability based on action, competition (Goodin, 2004), market conditions, so on and so forth. Various, including the above mentioned, definitions fairly justify to our hypothesis regarding the necessity to construct a cognitive cross-cultural thesaurus of the examined notion involving its possible mental representations in the two languages: English and Russian.

As the basic typology of accountability comprises its multilateral dimensions, regimes, mechanisms (Goodin, 2004) as well as the urgency of both bridging the gap between governance and the accountability and eliminating power abuses through accountability (Keohane, 2006), a thorough investigation of the pluralistic accountability system is being required for world politics ( $\mathrm{Ku}$, Jacobson, 2003).

Based on the said above, we claim that

- one of our basic axiomatic postulates considers the inner picture of the outer world of each person (a researcher, a translator) as well as the structure of his/her knowledge and associations as subjective and individual;

- in case of general universals dominating in the structure of the translator's knowledge the variant of translation finally chosen will be pattern-like (ordinary), while the original structure of knowledge - when trivial and traditional cognitive vision does not dominate in his/her mind and does not prevent a person from blending concepts that at first sight seem impossible to be blended - and the individual cognitive mind structure presuppose the emergence (often immediately, intuitively) of the original, non-standard decision;

- the task of a professional teacher of translation is obviously to stimulate the student's ability to involve the so-called "weak associative links" provoking in this way the original creative translation decision. 
Though research on translation creativity has been very limited and rarely found in accessible sources, our review of relevant literature has shown the general correlation typical for all of them: translation strategies discussion depends on the variable chosen in the research. The list of variables, as a rule, includes source text variables, target language variables, task variables, translator variables, socio-cultural variables and reception variables. Of all the variables enumerated above the task variables must be considered, in our view, as both most significant for the process of translation and possible to be taken into account in evaluating the so-called "degree of creativity". Besides the target (the task) of translation, the role of the commissioner, the client who commissions the translation, is often claimed as influencing the "degree of creativity used" in it. And I fully agree with this approach, as it is individuality that constitutes the greater part of the phenomenon of human creativity.

With this in view, I would like to start with explaining what exactly I mean by creativity in translation and how to differentiate between creative and non-creative translation decisions. Any act of creativity traditionally presupposes either the process of choosing between the alternatives, or the procedure of producing, making up, creating something absolutely new and original.

It was Theodore Savory, who in the second half of the twentieth century in his popular book "The Art of Translation" wrote that the continuous search for a successful translation variant of all possible alternatives and the very act of making a final choice was the essence of the creative nature of the translator's art (Savory, 1968: 26). Professor Vilen N. Komissarov, a prominent Russian translation researcher, wrote in one of his last papers that choice was the heart of all creating, and where there was no choice there was no room for ingenuity. Intuition and creativity as the highest functions of human mind are not easily accessible to analysis but the complexity of the task is no excuse for the refusal to tackle it. Translators training programs should be based on a proper understanding and an objective description of the translating process (Komissarov, 2004: 13).
Thus the creative translation decision is defined here as either the one chosen from the dictionary alternatives, or a totally new one definitely not fixed in any dictionary, and therefore it may be considered as a pure translation occasionalism whose actual contextual meaning immediately evaporates as soon as the problem original unit has been placed in another contextual discourse segment. All other translation decisions, beyond the above described category, are, consequently, regarded as non-creative, pattern-like. I see occasionalism as the fundamental theoretic concept in translation creativity understanding. It may be adequately "read off" and interpreted only by the representatives of a definite language and cultural community, who percept the reality around as the shared cognitive environment. Moreover, I suppose, that the abilities of a person to produce, "construct" linguistic (translation) occasionalisms influence his/her general intellectual - both verbal and non-verbal - potential and should be developed in every possible way, including its mastering in the course of translation practice.

I am particularly making it a point that I am writing about translation, and not about consecutive or conference interpreting, or any other type of oral translator's activity (which being not excluded from our empirical research base - presently lies beyond the frames of the given paper). It is recognized that the major purpose of a qualified translator is to adequately transfer the meaning of the original into the target language. But it is equally admitted that the multifaceted notion of "meaning" itself has still been vague, highly polysemantic, and has been interpreted variously and differently not only by researchers in linguistics, translation studies and cognitive science, but also by philosophers, sociologists, semioticians and representatives of many other related fields of science.

In our study meaning is understood, on the one hand, as a communicative information content entity, according to L.A. Chernyakhovskaya (2011), a leading Russian and now also American cognitive linguist and translation scientist, and on the other hand, according to T.A. Kazakova (2006), Professor of Transla- 
tion Studies at St. Petersburg State University (Russia), it is seen as a specific, often highly individual semiotic complex of a person's associations that exists in his/her mind and obligatory needs to be revealed and transferred in the process of translation from the source language into the target one (Kazakova, 2006: 133).

Verbal communication is exchanging communicative information, not just word meanings and sentence patterns, and translators should focus more on the information structure of messages, while the "mind grammar" invariant requires a new verbal re-shaping in the target language. Hence, "content entities of various ranks, as well as their information parameters, may be used as translation units of respective ranks" (Chernyakhovskaya, 2011: 284).

Therefore, our key problem issue states that the translator's thinking thesaurus may be seen as an individual combination of pivotal (steady) associative links and remote (weak) associative links, or, using Chernyakhovskaya's terminology (2011), "content entities of various ranks" that exist in a person's mind (in terms of the neuro paradigm, brain) and can be activated in the course of teaching translation by means of certain so-called "push-" or "trigger words" such as, for example - if to rely on the student's knowledge of translation theory - "context", "style" (formal, informal, neutral), "background" (linguo-specific, culture-specific, encyclopedic), etc. (Ubozhenko, 2012: 162).

In this connection, the methodology suggested here is focused on the idea of the "indicator word", "assistant word", "marker word" which performs the role of an intensifying incentive meant to push a translator (or a student who is learning translation) to making an equivalent and most adequate linguistic decision. This word, after having been identified through the detailed reflexive semantic analysis of the original unit, serves as an activator of the whole scope of a person's knowledge and as a trigger of those weak associative links which remain unconscious until the new categorization procedure has been deliberately forced upon the student by a professional teacher.
The metalinguistic algorithm involves such linguistic and cognitive tools as

- word-by-word translating,

- polysemy solving (relying on the context),

- meaning explicating and argumentative explaining,

- revealing communicative intentions of the original,

- distinct utterance's target formulating, and

- following (often intuitively) the "norms" of idiomatic (natural) correlation of separate word meaning elements.

The role of "triggers" in the course of cognitive discourse analysis may also be played by purely lexical key markers, in other words, core concepts (words, phrases, sentences and other utterances of different syntactical ranks) that can serve as pushing elements for activating sub-concepts or periphery notions.

The present research relies on the interdisciplinary methodology including

$\checkmark$ logical meditation,

$\checkmark$ analytical modeling,

$\checkmark$ cognitive and comparative analyses,

$\checkmark$ the synthesis of information learned with its further critical evaluation,

$\checkmark$ reflexive thinking,

$\checkmark$ making deductive/inductive conclusions.

\section{Research Design and Empirics}

We suggest our cognitive model of the ongoing processes that result in choosing an appropriate solution to the translation task: we see our scheme as the most completed and detailed description of the creative steps of the translator's search for the most adequate decision.

1. The first stage is devoted to shaping the background of the cognitive translation process that involves the entire complex of necessary multifaceted knowledge of linguistic, meta-linguistic and extra-linguistic kinds (in cognitive terms, the translator's backstage cognition formation). Here we imply:

1) the professional knowledge of the translator's working foreign languages;

2) general erudition and broad outlook; 
3) the knowledge in linguistics, lexicology, stylistics and some other language and linguistics courses;

4) background knowledge (the translation communicative situation, the knowledge of similarities and differences in conceptual world pictures of different national and cultural communities);

5) the knowledge in translation theory and understanding its actual links and relations to translation practices;

6) the professional translation competence regarding text producing, communicative, cognitive, technical skills as well as a certain set of personal skills and individual characteristics;

7) the knowledge in psychology, sociology, philosophy, political science as well as in a wide range of such relevant to linguistics subject fields as text linguistics, psycholinguistics, contrastive linguistics, sociolinguistics, pragmalinguistics, etc.;

8) the knowledge in disciplines beyond purely linguistic frames: from the culture history and literature history to socio-cultural and country/regional studies;

9) the understanding of the relation of translation to the author of the original, taking into account the author's intention;

10) the knowledge regarding phonological effects on translation (Snell-Hornby, 1988).

2. The second stage is aimed at combining the elements of that accumulated initial knowledge base, where comparison and selection lead to the search for a mental program image of all possible translation variants: here the meaning construction processes are researched through individual mind-mapping mental spaces analysis. This assumes:

1) shaping in the translator's consciousness the mental images of all possible translation versions of the original translation unit;

2) comparing the versions' message with regard to the context, then the stylistic formation of the translation verbal act;

3) choosing between the most adequate translation variants equivalent to the original message.
3. The third stage marks the final choice and taking a most adequate translation decision. Here we speak about:

1) the choice of the most appropriate equivalent version (relying on the idiomatic correlation concept, according to Apresyan I., the Russian linguist, researcher of lexical semantics);

2) the verbalization of a final translation solution made.

The practical part of the research conducted that proves the model validity consists of the two above mentioned illustrative cases. The first will very briefly demonstrate the importance of awareness of translation theory and the mechanism of context domination, while taking the adequate creative translation decision, illustrated by the example of translating a sentence from a short political context segment. The second one will dwell on translating a larger political discourse extract in detail.

\section{Example I.}

SL: Governing responsibly - as opposed to purely responsively - involves setting priorities and making difficult choices.

TL: Руководить ответственно - а не просто выполнять поставленные задачи - значит уметь расставлять приоритеты и принимать сложные решения.

Word by word back translation from Russian:

To govern with responsibility means to be able to rank priorities and take hard decisions and not just to perform the tasks set.

Step 1: explication of meaning and argumentative explanation.

Following the steady associative link in the process of our conscious speculating, the major meaning component to be revealed is "to give an appropriate feed back, if asked to accomplish a task".

Step 2: revealing communicative intentions of the original.

The word "purely" in the original bears the core emotional connotation of the whole problem phrase stressing that being in politics one should not act as a machine but think hard and analyze all the circumstances before actually acting. 
Step 3: formulating an adequate verbal translation decision (now consciously observing the rules of idiomatic correlation of all meaning elements of separate words).

The translator should verbalize the idea of "giving a smart conscious feed back as opposed / vs to the machine working" (which is a weak associate here, in the chain of purposeful meditations of a translator).

Hence:

$S L$ - as opposed to purely responsively

$T L$ - а не просто выполнять поставленные задачи

The linguistic decision described above is proved as creative as the Russian equivalent unit is far from being merely a word for word replacement by dictionary versions what justifies the status of the decision as a translation occasionalism.

\section{Example II.}

Here the cognitive scheme discourse analysis as the basis for making up an associative thesaurus is presented.

The below given analyzed discourse quotation 1 is referred to the concept of accountability and its cognitive structure.

\section{SL:}

What Do We Mean by Accountability, Anyway?

During 1998, for example, questions about President Bill Clinton's campaign fundraising and personal behavior generated numerous calls to hold someone accountable. "Perjury," said U.S. Representative (and speaker designate) Bob Livingston when he announced his retirement from Congress, "is a crime for which the president may be held accountable, no matter the circumstances." Former senator Bob Dole criticized Attorney General Janet Reno's failure to appoint an independent counsel to investigate the fundraising practices of the 1996 Clinton-Gore campaign committee and hoped that "someone in Congress will hold the attorney general accountable." Allegations of Chinese espionage at U.S. nuclear laboratories caused Senate Majority Leader Trent Lott to remark that somebody "made some major mistakes, and somebody needs to be held accountable." Everyone wants people - other people - to be held accountable. Mark Moore of Harvard University and Margaret Gates, a consultant to nonprofit agencies, write of "the public's demand for accountability," of "an unquenchable thirst for accountability that cuts across the political spectrum."
...Those whom we want to hold accountable have a clear understanding of what accountability means: Accountability means punishment. This punishment can be a fine, a jail term, the loss of one's job - all of which are subject to the requirements of due process. But the punishment can also be the public humiliation of being grilled by a hostile legislator, of being sued by an aggressive lawyer, of being subpoenaed by an unctuous prosecutor, or of being defamed by an investigatory journalist - none of which requires much due process. When people screw up, there are a variety of ways to hold them accountable - to punish them (Behn, 2001: 73).

The following discourse quotation 2 analyses the sub-notion of mutual accountability, its cognitive scheme analysis and Russian translation version. Words marked in italics and underlined words in both quotations as well as in the translation indicate the units identified as nuclear, associative, and then steady and weak associate ones respectively by using our original cognitive mind-mapping methodology (see Table 1), which combines the linguistic grammar technique known as "core-shell" analysis with the analytical political science method of "conceptual stretching" - first introduced by Sartory - aimed at concepts' categorization and classification (see: Collier \& Mahon, 1993).

\section{$S L$ :}

Mutual accountability requires cooperation. A compact of mutual, collective responsibility is designed to foster that cooperation among the web of people and organizations in the accountability environment. The parties to such a compact would seek to establish the terms under which they - and, they hope, others in the accountability environment would cooperate to enhance government performance, subject to some agreed-upon constraints to ensure the proper use of finances and the equitable treatment of people.

Indeed, without such a responsibility compact for performance, those seeking to improve performance may be unable to move beyond an obsession with the rules for finances and fairness. Who, however, will agree to cooperate? Who will sign on to a "compact" that guarantees nothing more than experimentation? Who will trade individual accountability for mutual accountability?

Who (besides a public manager) will trade his or her well-understood (and relatively limited) individual 
Table 1. Final Table Based on Cognitive Mind-Mapping Scheming

\begin{tabular}{|c|c|c|c|}
\hline \multicolumn{4}{|c|}{ Cognitive Mind-Mapping Scheme } \\
\hline 1. nuclear units & 2. associative units & 3. steady associates & 4. weak associates \\
\hline \multirow[t]{2}{*}{ 1. Accountability } & \multirow[t]{2}{*}{ accountable } & $\begin{array}{l}\text { to hold someone } \\
\text { accountable }\end{array}$ & \multirow[t]{2}{*}{ punishment } \\
\hline & & to be held accountable & \\
\hline 2. Measures of Performance & $\begin{array}{l}\text { the public's thirst } \\
\text { for accountability }\end{array}$ & by suing & by convincing juries \\
\hline 3. Mechanisms of accountability & the accountability system & $\begin{array}{l}\text { accountability holder } \\
\text { accountability holdee }\end{array}$ & $\begin{array}{l}\text { official and unofficial } \\
\text { accountability holders }\end{array}$ \\
\hline $\begin{array}{l}\text { 4. Hold someone [in government] } \\
\text { accountable }\end{array}$ & punishment & jail term & the public humiliation \\
\hline
\end{tabular}

accountability (often defined by professional peers) for some vague sense of mutual, collective responsibility that will be devised, refined, and revised sometime in the future by people with unknown or even incompatible values? Who has an incentive to cooperate? And even if people do sign on to such a responsibility compact, will they remain bound by this informal (and not very enforceable) agreement? Who has an incentive to continue to cooperate? (Behn, 2001: 129).

\section{TL (transliteration of the Russian ver-} sion):

Kollektivnaja podotchjotnost' trebuet sotrudnichestva. Soglashenie o vzaimnoj kollektivnoj otvetstvennosti naceleno na iniciirovanie takogo sotrudnichestva mezhdu vzaimodejstvujushhim i vzaimosvjazannym soobshhestvom ljudej i organizacij, funkcionirujushhih $\mathrm{v}$ srede podotchjotnosti. Storony podobnogo soglashenija budut stremit'sja zakrepit' uslovija, pri kotoryh oni - i, kak oni predpolagajut, drugie uchastniki jetoj sredy podotchjotnosti - budut sotrudnichat's cel'ju uluchshenija dejatel'nosti pravitel'stva, pri uslovii nekotoryh ogovorjonnyh ogranichenij, garantirujushhih dolzhnoe ispol'zovanie finansov i dostojnoe otnoshenie $\mathrm{k}$ ljudjam.

Bezuslovno, pri otsutstvii podobnogo soglashenija o vzaimnoj otvetstvennosti $\mathrm{v}$ processe ih dejatel'nosti, te, kto stremjatsja povysit' kachestvo poslednej, mogut okazat'sja ne v sostojanii prodvinut'sja dalee polnogo pogruzhenija $\mathrm{v}$ ramki razumnogo rashodovanija finansovyh sredstv i spravedlivogo obrashhenija s grazhdanami. Kto zhe, odnako, soglasitsja pojti na takoe sotrudnichestvo? Kto soglasitsja podpisat'sja pod soglasheniem, kotoroe ne garantiruet nichego, krome uchastija v nekom jeksperimente? Kto soglasitsja promenjat' individual 'nuju otvetstvennost' na vzaimnuju podotchjotnost'?

Kto (pomimo gosudarstvennogo upravlenca) soglasitsja promenjat' emu/ej horosho ponjatnuju (i otnositel'no ogranichennuju) individual'nuju otvetstvennost' (zachastuju opredeljaemuju professional'nymi jekspertami) na nekoe razmytoe chuvstvo vzaimnoj, kollektivnoj otvetstvennosti, ponjatie kotorogo budet razrabotano, a kogda-nibud' v budushhem otkorrektirovano i peresmotreno ljud'mi, cennosti kotoryh neizvestny ili voobshhe somnitel'ny? U kogo est' stimul sotrudnichat'? I esli dazhe kto-to v itoge podpishetsja pod podobnogo roda soglasheniem o vzaimnoj otvetstvennosti, budet li jetot chelovek po-prezhnemu ostavat'sja svjazannym dannymi neformal'nymi (i ne osobo real'no vypolnimymi) objazatel'stvami? U kogo est' stimul prodolzhat' sotrudnichat'?

\section{Results Obtained and Anticipated}

1. In this connection, the analysis performed has shown that the steady associative links regarding the important but still elusive and even murky (as R. Behn (2001) puts it) notion of accountability comprise such core fields of conceptual meaning as "holding people accountable", "responsibility", "the accountability system and its mechanisms", "liability" and "answerability", "responsiveness" (Morlino, 2009), and some others.

2. Simultaneously the accountability concept covers such periphery notions (or sub-notions based on the weak associative links traced in the analyzed discourse) as "the accountability holder" (including regulators and legislatures, politicians, auditors, lawyers 
and, what is more interesting, scholars and journalists) and "the accountability holdee" represented, in its turn, by the President, government officials, government bureaucracies, an agency's clients, managers, donors, taxpayers and a number of other players and stakeholders each of whom may be researched as a separate push-notion (theoretically considered as a steady associative link).

3. Of high research interest may be such associative derivatives of "accountability" as "the accountability environment" (in contrast with, at first sight, close, but actually different semantic field and reality notion of "the accountability system") and a very resourceful and controversial weak associate of "punishment" (never mentioned in any dictionaries as a connotation part of the meaning of the word "accountability") leading not only to the traditional things understood by it such as fines, jail terms and the loss of one's job, but also to such an associative link as "the public humiliation" (for some "wrongdoing") which may be extremely useful as a part of the whole thesaurus regarding the concept of accountability.

4. The cognitive discourse analysis of the sub-notion of mutual accountability is associated with government performance that has definitely to be improved, with the controversy of individual and collective values as well as with an informal responsibility compact and the necessary incentive to cooperate.

5. All cognitive elements of the concept under study identified and mentioned above were taken into account, when the presented here versions of the translation were being made by the author of the paper.

6 . The creative model of teaching translation has been introduced, suggesting an original way of the cognitive scheme discourse analysis and new didactic devices used in developing linguistic creativity through training translation. The author's idea of a "translation creative occasionalism" has been explained in the paper.

7. The research of language creativity has been carried out by performing a cognitive discourse analysis of the extracts from foreign language texts abounding in modern political terminology.
8. The study proves that the experience of reflexive thinking is necessary, while searching for the right associative "prompt", "push-stimulus", "trigger-words" leading to making the translator's creative choice (often intuitively) that finally results in choosing the most acceptable variant of translation and following certain definite conscious methodological steps (the algorithm).

9. All the analyzed notions and sub-notions need an adequate interpretation in Russian with its further implanting in the mental thesaurus of both the Russian ordinary speakers and professional political scientists.

\section{Conclusions and Prospects for Further Research}

Despite often expressed academic misgivings and prejudices regarding the possibility and scientific usefulness of the attempts to research and, what is more, teach creativity, it has apparently been found that to teach linguistic and translation creativity is methodologically justified and valuable.

I particularly stress that it can hardly be overestimated that all the prospects for researching creativity as a whole should necessarily lie in the field of multidisciplinary studies in the Humanities and social sciences, political science including. The model of teaching creative translation is obvious to be necessarily based on mastering the skills of individual interpreting the reality around that means training the ability to think, to meditate logically, reflexively, consciously and purposefully in order to argumentatively and again consciously choose the variant of a final decision. If a translator has had that kind of learning experience, in case the accumulated un(sub)conscious techniques should be required in a problem situation, they will definitely emerge in the memory triggered by his/her intellectual efforts to produce the targeted professional decision, adequate in the given circumstances.

Following L.A. Chernyakhovskaya (2011), we assume the element of creativity in the process of translation has been fairly proved by the fact that "some information components implicit in the original become explicit in a translation, and vice versa, as they are addressed to 
people of different cultures. Depending on the peculiarities of a target language, a translation may suggest a different verbal presentation". The creative variety of information verbal presentation surely needs special research, which may result in a very different - cognitive, interpretative, creative - translation theory that would "shed more light on the translation/interpretation process, seriously assist in improving the quality of translation in general and become an important tool in understanding and mastering translation/interpretation process, as well as in qualified interpreters/translators training" (Chernyakhovskaya, 2011: 298). In its turn, actualized translation versions will make a profound grounding for the construction of adequately conceptualized and operationalized academic terminology extremely necessary for any professional research, the political science field being no exception.

Training translation proficiency should be based on the profound comprehension of all factors needed for the production of a successful translation solution. Students should be taught objective methods of describing the translation process. The creative ability of a translator to interpret the original may be developed, while their actual working as well as in the course of specialized training with a certain complex of exercises and creative translation tasks to be solved. In my view, it is the activation of translation intuition that serves as the key foundation of the translator's creative and interpretive skills. This mental act/state may be seen as the actual practical/professional use of the accumulated cognitive experiences discreetly, tightly folded in the human memory, cognition and consciousness. Besides many other necessary methods and translation decision making ways, such proficiency contains a certain classified/categorized instrumental tool kit of typical well-mastered empirical solutions. In terms of synergy here we may speak of a self-constructing process of mind structures (visual and mental images, ideas, representations) on the ground of brain and in the field of consciousness at its two stages: when combining/comparing the versions and when making a final decision. It is significant to stress that the translator is able to explain, why his/her variant seems to be the most adequate in that very context, and to give reasons for that solution only post factum, when the task has been already solved, and never exactly at the moment, when the so-called twinge of intuition or insight emerges.

\section{References}

Apresyan, I.D. (1995). Izbrannye trudy: V 2 t. [Selecta: In 2 vols.]. Vol. 1: Leksicheskaia semantika. Sinonimicheskie sredstva iazyka [Lexical Semantics. Synonymous Resources of Language]. Moscow, Jazyki russkoj kul'tury, Vostochnaia literatura Publ., 480 p.

Behn, Robert B. (2001). Rethinking Democratic Accountability. Washington, DC: Brookings Institution Press.

Chernyakhovskaya, L.A. (2011). The Structure of Text Contents. In Russian Journal of Communication, 4, Nos. $3 / 4$ (Summer/Fall 2011).

Collier, D. and Mahon, J.E. (1993). Conceptual "stretching" revisited: adapting categories in comparative analysis. In The American Political Science Review, 87 (4), 845-855.

Democratic accountability and the use of force in international law (2003). Edited by Ch. Ku and H.K. Jacobson. Cambridge University press.

Diamond, L. and Morlino, L. (2004). The Quality of Democracy. An overview. In Journal of Democracy, 15 (4). October 2004, 20-31.

Goodin, R.E. (2004). Democratic Accountability: The Third Sector and All. Paper presented to Seminar series on "Institutional Analysis of Law, Politics, and Society". Baldy Center for Law \& Social Policy. Social \& Political Theory and Philosophy Programs. Research School of Social Sciences. Australian National University. Canberra, Australia. 73 p.

Held, D. (2004). Democratic Accountability and Political Effectiveness from a Cosmopolitan Perspective. $36 \mathrm{p}$. 
Kazakova, T.A. (2006). Hudozhestvennyi perevod: teorija i praktika. [Literary Translation: Theory and Practice]. St. Petersburg: "ForeignLang. Publishing House".

Keohane, R.O. (2006). Accountability in World Politics. In Journal compilation. Nordic Political Science Association. Scandinavian Political Studies, 29 (2), 75.

Keohane, R.O. (2002). Global Governance and Democratic Accountability. Chapter prepared for a volume to be edited by David Held and Mathias Koenig-Archibugi from the Miliband Lectures, London School of Economics. Duke University, Department of Political Science, Durham.

Komissarov, Vilen N. (2004). On Linguistic Basis of Creativity in Translation. In La Traduzione. Saggi E Documenti. Quaderni di Libri e Riviste D'Italia, 33.

Morlino, L. (2009). Qualities of Democracy: How to Analyze Them. Istituto Italiano di Scienze Umane, Florence (Italy). 43 p.

Savory, Th.H. (1968). The Art of Translation. London: Jonathan Cape, Thirty Bedford Square.

Sharpf, F.W. (2003). Problem solving, Effectiveness, and Democratic Accountability in the EU. 37 p.

Schmitter, Ph.C. (2004). The Ambiguous Virtues of Accountability. In Journal of Democracy, 15 (4), October 2004, 47-60. DOI: 10.1353/jod.2004.0073

Snell-Hornby, M. (1988). Translation Studies. Integrated Approach. Amsterdam, Philadelphia, John Benjamins Publ., 180 p.

Sousa, P.A.B. (2002). Central Bank Independence and Democratic Accountability. Portugal. 26 p.

Stasavage, D. (2003). Transparency, Democratic Accountability, and the Economic Consequences of Monetary Institutions, 389-402.

Ubozhenko, I.V. (2012). The Theoretical Basis of a Linguo-Didactic Model of Developing Creativity in Translation: "Push-Word" Methodology, Prospects for the Neurolinguistic Approach. In Abstracts of 4th UK Cognitive Linguistics Conference (London: King's College). 


\title{
Когнитивный анализ политического дискурса: обучение поиску творческих переводческих решений
}

\author{
И.В. Убоженко \\ Национальный исследовательский университет \\ «Выстая школа экономики» \\ Российская Федераџия, Москва
}

\begin{abstract}
Аннотация. Данное исследование предлагает авторскую концепцию обучения творческому переводу на примере возможного алгоритма когнитивного анализа отрывков политического дискурса. Особый интерес представляет тот факт, что материалом изучения послужила современная политологическая терминология и ряд примеров безэквивалентной лексики в рамках политического контекста. В отличие от традиционного подхода к пониманию творчества применительно только к художественным текстам в статье анализируются переводческие аспекты англоязычной терминосистемы на базе научных и академических источников. Когнитивный анализ контекстуальной актуализации конкретных политических концептов в англоязычном и русскоязычном дискурсах служит инструментом сравнения и профессионального объяснения причин выбора соответствующих переводческих эквивалентов. Предлагаемый алгоритм построения ассоциативного тезауруса на основе когнитивных схем и лексических маркеров используется автором в исследовании как главный способ политического дискурс-анализа и как эмпирическая основа оригинальной творческой модели обучения поиску нестандартных переводческих решений.
\end{abstract}

Ключевые слова: политический дискурс, обучение переводческому творчеству, интуиция в переводе, когнитивное моделирование перевода.

Научная специальность: 10.02.20 - сравнительно-историческое, типологическое и сопоставительное языкознание. 